\title{
KEJADIAN PNEUMONIA BALITA DI MAUMERE FLORES NUSA TENGGARA TIMUR
}

\author{
Vivian Nanny Lia Dewi ${ }^{1}$, Silvia Ari Agustina ${ }^{1}$ \\ ${ }^{1}$ Program Studi Kebidanan, Stikes Jenderal A Yani Yogyakarta, Jl. Ring Road Barat Ambarketawang, Gamping \\ Sleman, Yogyakarta 55294, Indonesia. Email: umivivian@gmail.com
}

\begin{abstract}
Background: Pneumonia is the most significant disease to cause death in children compared to any other respiratoy infections, particularly in babies and children under five years old.

Objective: This study aimed to investigate several risk factors for pneumonia in children under five years old in Maumere, Flores, NTT.

Methods: This sudy employed collaborative qualitative-quantitative design. Data on the occurrence of pneumonia were drawn from the medical record of TC Hillers Maumere hospital, gathering information from January to July 2015. Research also involved direct observation to residents housing and interviews with health care providers and locals. Research population was children under five with a history of pneumonia, consisted of 152 children. Data were alayzed with a univariate method.

Results: The majority of respondents with pneumonia were male $(53.3 \%)$, co-morbid with iron deficiency anemia (20.4\%), aged under 12 months $(69.1 \%)$, well-nourished $(56.6 \%)$, and waiting for $1-3$ days at home before going to the hospital (47.5\%). Direct observation suggested that Maumere was a dry and dusty area. The majority of housing roof was zinc, with topsoil floor, house ventilation were not properly adjusted, houses were over-populated, and residents still used wood and gasoline to cook. Residents had strong belief on supernatural powers.

Conclusion: Risk factors that increased the occurrence of pneumonia in children under five in Maumere were age, sex, nutritional status, and environment characteristics.
\end{abstract}

Keywords: pneumonia, anemia, nutrition, housing, children

\section{PENDAHULUAN}

Pneumonia merupakan penyakit paling serius dan paling membahayakan jiwa anakanak dibandingkan dengan infeksi saluran pernapasan lainnya terutama pada bayi dan anak berusia di bawah lima tahun. Dari tahun ke tahun pneumonia selalu menduduki peringkat atas dalam hal penyebab kematian bayi dan anak balita Indonesia. ${ }^{(1)}$

Pneumonia merupakan penyebab utama kematian anak di dunia dimana diperkirakan membunuh sekitar 1,2 juta anak berusia di bawah lima tahun (balita) dalam setiap tahunnya. Hal ini melebihi AIDS, malaria, dan
TB. Pneumonia dapat disebabkan oleh virus, bakteri, maupun jamur. ${ }^{(2)}$

Faktor risiko yang menyebabkan tingginya angka mortalitas pneumonia pada anak balita di negara berkembang antara lain adalah pneumonia yang terjadi pada masa bayi, berat badan lahir rendah (BBLR), bayi tidak mendapatkan imunisasi, tidak mendapatkan asupan ASI yang adekuat, malnutrisi, tingginya prevalensi kolonisasi bakteri patogen di nasofaring, dan tingginya pajanan terhadap polusi udara. ${ }^{(3)}$

Distribusi insiden pneumonia balita dari seluruh provinsi di Indonesia berdasarkan hasil 
Riskesdas di tahun 2013 yaitu lima propinsi yang mempunyai insiden pneumonia balita tertinggi adalah Nusa Tenggara Timur (38,5\%), Aceh (35,6\%o), Bangka Belitung (34,8\%o), Sulawesi Barat (34,8\%o), dan Kalimantan Tengah (32,7\%o). Insiden tertinggi pneumonia balita terdapat pada kelompok umur 12-23 bulan $(21,7 \%$ ). Pneumonia balita lebih banyak dialami pada kelompok penduduk dengan kuintil indeks kepemilikan terbawah $(27,4 \% \circ){ }^{(4)}$ Hasil Riset Kesehatan Dasar (Riskesdas) propinsi Nusa Tenggara Timur tahun 2008 menyebutkan bahwa prevalensi pneumonia yang relatif tinggi dijumpai di Kabupaten Manggarai, Ngada, dan Sumba Barat. ${ }^{(5)}$ Studi ini bertujuan untuk melihat gambaran kejadian pneumonia pada balita yang terjadi di Maumere, Flores, NTT.

\section{BAHAN DAN CARA PENELITIAN}

Penelitian Kolaboratif Kualitatif-Kuantitatif, yang dilakukan di Maumere, Flores, NTT. Di mana data Balita pneumonia diambil dari data rekam medis balita pneumonia di RS TC Hillers Maumere dari bulan Januari-Juli 2015. Populasi yang digunakan dalam penelitian ini meliputi 152 sampel kuantitatif yaitu balita pneumonia dan 3 sampel kualitatif yaitu 2 orang petugas kesehatan dan 1 orang warga setempat. Pengambilan data dilakukan dengan pengambilan data rekam medis balita pneumonia di RS TC Hillers dan observasi secara langsung ke daerah pemukiman warga, wawancara dengan petugas kesehatan di RS TC Hillers dan warga setempat. Teknik sampling yang digunakan adalah Total Sampling dan analisis data secara triangulasi dan univariat.

\section{HASIL DAN PEMBAHASAN}

Tabel 1 Karakteristik Responden Berdasarkan Jenis Kelamin

\begin{tabular}{lcc}
\hline \multicolumn{1}{c}{ Jenis Kelamin } & F & $\%$ \\
\hline Laki-laki & 81 & 53.3 \\
Perempuan & 71 & 46.7 \\
\hline
\end{tabular}

Tabel 2 Karakteristik Responden Berdasarkan Penyakit Penyerta

\begin{tabular}{lcc}
\hline \multicolumn{1}{c}{ Penyakit Penyerta } & F & $\%$ \\
\hline Tidak ada & 70 & 46.1 \\
Penyakit kompleks & 12 & 7.9 \\
TB Paru & 2 & 1.3 \\
Gastro Enteritis Akut & 7 & 4.6 \\
Anemia Defisiensi Besi & 31 & 20.4 \\
Dengue Haemorhage & 2 & 1.3 \\
Fever & & \\
Bronchiolitis & 3 & 2.0 \\
Malaria & 1 & 0.7 \\
Tetanus & 2 & 1.3 \\
Jantung & 6 & 3.9 \\
Asma & 6 & 3.9 \\
Penyakit Kulit & 3 & 2.0 \\
Sepsis & 1 & 0.7 \\
Down Syndrome & 1 & 0.7 \\
Gizi Buruk & 5 & 3.3 \\
\hline
\end{tabular}

Tabel 3 Karakteristik Responden Berdasarkan Umur

\begin{tabular}{lcc}
\hline \multicolumn{1}{c}{ Umur } & $\mathbf{F}$ & $\%$ \\
$<12$ bulan & 105 & 69.1 \\
$12-60$ bulan & 47 & 30.9 \\
\hline
\end{tabular}


Tabel 4 Karakteristik Responden Berdasarkan Status Gizi dan Lama Keluhan di Rumah Sakit

\begin{tabular}{ccc}
\hline Karakteristik & F & $\%$ \\
Status Gizi & & \\
Gizi buruk & 31 & 20.4 \\
Gizi Kurang & 33 & 21.7 \\
Gizi Baik & 86 & 56.6 \\
Gizi Lebih & 2 & 1.3 \\
Lama Keluhan di Rumah & & \\
1-3 Hari & 48 & 47.5 \\
4-7 Hari & 43 & 42.6 \\
8-14 Hari & 6 & 5.9 \\
15-30 Hari & 3 & 3 \\
>30 Hari & 1 & 1 \\
\hline
\end{tabular}

Tabel 1-4 Menunjukkan bahwa dalam kurun waktu 7 bulan, kejadian pneumonia balita di RS rujukan TC Hillers tercatat sebanyak 152 kasus, sebagian besar penderita pneumonia adalah balita laki-laki (53.3\%), penyakit penyerta paling banyak adalah anemia defisiensi besi (20.4\%), usia kurang dari 12 bulan (69.1\%), Gizi Baik (56.6\%), walaupun sebagian besar penderita pneumonia mempunyai status gizi yang baik, akan tetapi prevalensi balita dengan status gizi kurang dan buruk masih tinggi yaitu $21.7 \%$ dan 20.4\%. Lama keluhan di rumah sebelum dibawa ke rumah sakit sebagian besar adalah 1-3 hari (47.5\%), meskipun pada beberapa kejadian, orang tua/keluarga membawa anak ke rumah sakit setelah lewat dari 14 hari.

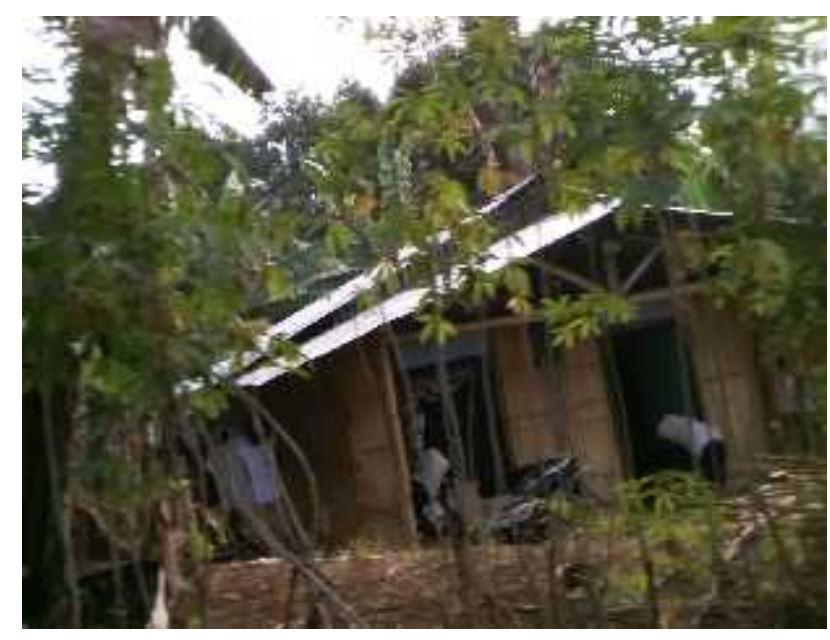

Gambar 1. Rumah di Daerah Pedesaan Maumere

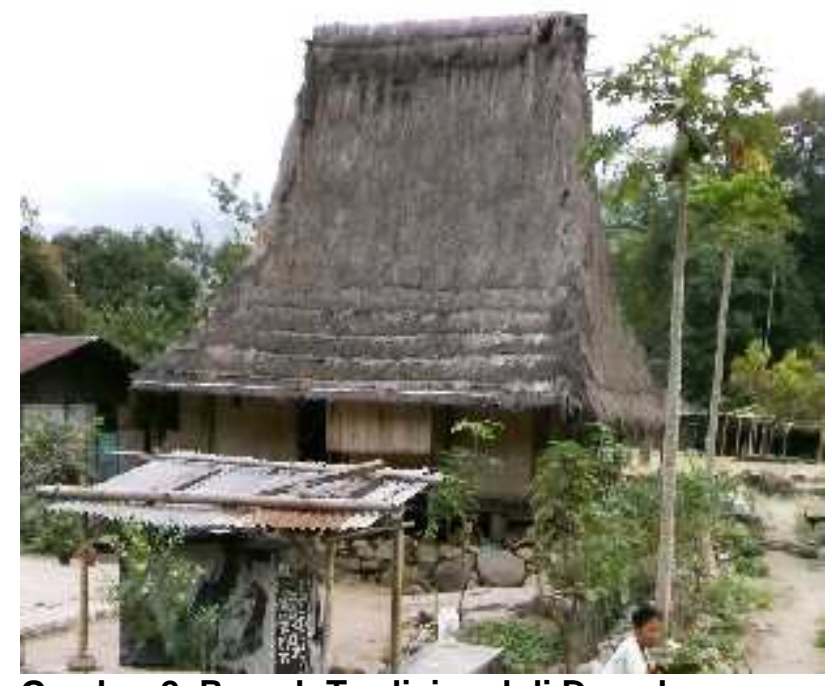

Gambar 2. Rumah Tradisional di Daerah Pedesaan Maumere

Berdasarkan gambar 1 dan 2, rumah di daerah pedesaan Maumere menggunakan atap seng dengan dinding kayu atau bilahan bambu, beberapa beralaskan tanah dan beberapa yang masih menggunakan rumah tradisional dengan beratapkan jerami. Setiap rumah sudah diberi ventilasi, tetapi belum berfungsi maksimal karena selalu tertutup dan bahkan tidak bisa dibuka karena ditutupi bilahan bambu. 
Angka kejadian pneumonia pada balita di Flores, NTT, khususnya di Maumere sangat tinggi. Terbukti dalam kurun waktu Januari-Juli 2015 didapatkan sejumlah 152 balita penderita pneumonia di rumah sakit TC Hillers sebagai salah satu rumah sakit rujukan di Flores. Hal ini tidak terlepas dari faktor risiko pencetus pneumonia yang sangat kompleks, misalnya umur, jenis kelamin, status gizi, dan karakteristik lingkungan.

Dari data penelusuran rekam medis, didapatkan bahwa sebagian besar penderita pneumonia adalah balita laki-laki (53.3\%) lebih rentan terkena pneumonia, sehingga harapan hidupnya lebih rendah daripada perempuan, terbukti dari data Kementerian Kehutanan Nusa Tenggara Timur tahun 2011, disebutkan bahwa jumlah penduduk perempuan lebih besar daripada penduduk laki-laki. Hal ini secara tidak langsung menunjukkan bahwa harapan hidup perempuan lebih tinggi dibandingkan laki-laki.

Selain itu, sebagian besar kasus pneumonia di Maumere, Flores, selalu disertai dengan penyakit yang lain misalnya TB paru, gastro enteritis akut, anemia defisiensi besi, dengue haemorhage fever, bronchiolitis, malaria, tetanus, jantung, asma, penyakit kulit, sepsis, down syndrome, dan gizi buruk, dan penyakit penyerta paling banyak adalah anemia defisiensi besi (20.4\%). Hal senada juga disampaikan oleh informan MG, bidan jaga di bangsal anak:
"Pasien dengan pnemonia banyak penyakit penyerta seperti gizi buruk, GE, kejang demam, anemia dan BP murni hanya beberapa, bahkan ada yang dengan marasmus."

Sebagian besar balita pneumonia mempunyai status gizi baik (56.6\%), walaupun sebagian besar penderita pneumonia mempunyai status gizi yang baik, akan tetapi prevalensi balita dengan status gizi kurang dan buruk masih tinggi yaitu $21.7 \%$ dan $20.4 \%$. Berdasarkan hasil Riskesdas tahun 2013, diantara 33 provinsi di Indonesia, 18 provinsi memiliki prevalensi gizi buruk-kurang di atas angka prevalensi nasional yaitu berkisar antara 21,2 persen sampai dengan 33,1 persen. Urutan tertinggi adalah Nusa Tenggara Timur. ${ }^{(4)} \mathrm{Hal}$ ini tentunya tidak lepas dari banyak faktor yang mempengaruhi, salah satunya adalah adanya budaya pantang makan makanan tertentu yang dilakukan oleh beberapa suku di Flores, seperti yang disampaikan dari informan MG:

"Untuk budaya makanan disini tergantung dari sukunya, ada suku yang pantang makanan-makanan tertentu, seperti suku liau itu mereka berpantang makanan yang tinggi protein, jadi untuk telur dan daging, banyak anak-anak dilarang makan. Kadang orang luar yang datang kesini itu merasa lucu, karena banyak nelayan tetapi makanannya telur, tidak ikan."

Hal ini didukung juga oleh pernyataan masyakat setempat, Informan EC:

"Sebagian besar makan sehari 3 kali. Masyarakat di sini kebanyakan nelayan, tapi jarang makan ikan, kalaupun makan ikan pasti kepalanya dibuang atau tidak dimakan. Ada beberapa suku di tempat kami yang melarang makan daging, telur, ikan dan anaknya walaupun masih balita sekalipun juga dilarang. 
Kami masak untuk keluarga kami sendiri, jarang atau bahkan tidak ada orang Maumere asli yang buka warung."

Dan juga pernyataan Informan MB:

"Untuk pantangan makanan, sebenarnya didaerah-daerah tertentu ada, dan sebenarnya ada hubungannya juga dengan kesehatan. Seperti untuk mengurangi makananmakanan berprotein seperti telur, pola makan yang salah. Bayi 0-6 bulan rata-rata masih bagus, tetapi untuk bayi yang lebih dari 6 bulan yang sudah diberi makanan tambahan, disitu banyak balita yang berat badannya turun banyak."

Kekurangan nutrisi pada anak mempunyai risiko tinggi terhadap kematian pada anak usia 0-4 tahun. Kekurangan nutrisi merupakan faktor risiko terjadinya penyakit pneumonia, hal ini disebabkan karena lemahnya sistem kekebalan tubuh karena asupan protein dan energi berkurang, dan kekurangan gizi dapat melemahkan otot pernafasan. ${ }^{(5)}$

Kesadaran masyarakat untuk segera memeriksakan anaknya ke rumah sakit yang terlihat pada data lama keluhan di rumah sebelum dibawa ke rumah sakit sebagian besar adalah setelah 1-3 hari (47.5\%), meskipun beberapa kejadian, orang tua/ keluarga membawa anak ke rumah sakit setelah lebih dari 14 hari bahkan sampai 3 bulan. Hal ini dipengaruhi oleh banyak faktor, misalnya geografis, dari data Kementerian Kehutanan Nusa Tenggara Timur, 2011, kondisi prasarana jalan perhubungan darat pada wilayah pesisir di Kabupaten Sikka yang belum diaspal sepanjang $237.132 \mathrm{~km}^{(6)}$

Transportasi darat masih cukup sulit, hanya beberapa angkutan pedesaan (seperti truk) yang melayani wilayah yang jauh. Transportasi alternatif lainnya adalah usaha motor ojek. Hal ini membuat warga cenderung menunggu beberapa hari di rumah sebelum dibawa ke rumah sakit, sampai kira-kira dapat disembuhkan oleh dukun, jika tidak dapat sembuh, maka akan dirujuk ke rumah sakit, berdasarkan pernyataan informan MG:

"Namanya masyarakat kadang kesadaran untuk berobat kurang, anak-anak kadang-kadang dibiarkan batuk selama satu minggu lebih baru berobat. Budaya orang sini juga masih memegang tradisional seperti berobat kedukun dulu, pokoknya sebelum ditangani di faskes sudah ditangani ke dukun dulu."

Informan MB:

"Kesadaran untuk berobat anak dengan batuk pilek sebagian besar masih sangat kurang, ditunggu lama-lama dulu sekitar 1 minggu lebih tidak sembuh baru dibawa kerumah sakit dan rata-rata yang masuk $R S$ dengan pnemonia ini diawali dengan batukbatuk sekitar 1 sampai 2 minggu terus sesak. Mungkin awalnya hanya batuk flu biasa lamalama dibiarkan jadi pnemonia."

Karakteristik lingkungan di daerah Maumere, Flores juga sangat mendukung tingginya angka kejadian pneumonia balita, misalnya lingkungan fisik, sosial, kepadatan hunian. Ventilasi rumah, polusi udara dalam ruangan. Pada gambar 1 dan 2, terlihat jelas rumah-rumah warga daerah Maumere, Flores dan lingkungannya, dimana kondisi lingkungan sekitar kering dan berdebu dan dan masih beralaskan tanah diperkuat oleh pernyataan informan $\mathrm{MB}$ :

"Disini itu ada musim-musim tertentu seperti kemarau yang panjang, sehingga air kurang, daerah yang banyak debu, sehingga anak-anak rentan mengalamai pnemonia." 
Senada dengan informan $\mathrm{MB}$, informan MG juga memaparkan tentang rumah-rumah di kampung yang masih banyak yang beralaskan tanah, mereka hanya membentangkan tikar, anaknya dibiarkan bermain, bahkan banyak anak yang dibiarkan bermain ditanah, padahal lingkungan sangat berdebu. Berdasarkan keterangan Informan MB:

"Budaya perumahan disini adalah jika dikota mungkin sudah sebagian besar tembok, akan tetapi yang di kampung atau diluar kota, masih banyak yang hanya sebagian tembok sebagian kayu, dan ada juga yang dari bambu cincang dan bahkan masih ada banyak yang beralaskan tanah. Disini gentingnya hampir semua menggunakan seng."

Resiko pneumonia meningkat secara bermakna (nilai $p<0,05$ ) pada kelompok balita yang tinggal di rumah dengan jenis lantai tanah. ${ }^{(7)}$

Rumah-rumah sebagian besar masih beratapkan seng. Alasan warga menggunakan atap seng diungkapkan oleh Informan EC:

"Untuk antisipasi gempa yang sering melanda Maumere, dan juga masyarakat sini masih trauma dengan gempa yang diikuti tsunami hebat dulu tahun 1992. Memang sih jadi panas banget di dalam ruangan. Apalagi kalau siang. Matahari di sini juga lebih terik."

Suhu yang panas dapat meningkatkan penguapan di dalam ruangan sehingga tidak hanya kelembaban yang meningkat tetapi juga kandungan pencemar yang berasal dari bahan bangunan rumah. Kelembaban yang tinggi (> $80 \%$ ), yang berarti kandungan uap air di udara cukup tinggi, merupakan kondisi yang baik untuk pertumbuhan dan kelangsungan hidup sel bakteri (pneumococus) sehingga bakteri dapat tumbuh dengan cepat. ${ }^{(8)}$

Untuk jarak rumah di daerah Maumere tidak sepadat di Jawa, jarak rumah normal. Rumah ditempati bisa lebih dari 1 keluarga atau anak yang sudah menikah tinggal bersama-sama, atau dibuatkan dilingkungan sekitar rumah keluarga. Banyaknya orang yang tinggal dalam satu rumah mempunyai peranan penting dalam kecepatan transmisi mikroorganisme di dalam lingkungan, sehingga kepadatan hunian rumah perlu menjadi perhatian semua anggota keluarga, terutama dikaitkan dengan penyebaran penyakit menular.

Berdasarkan penelitian yang dilakukan di Kebumen dengan jumlah sampel 68 dengan menggunakan desain case control, menunjukkan bahwa sebagian besar balita penderita pneumonia $(83,8 \%)$ tinggal di rumah dengan kondisi padat. $^{(9)}$ Semakin banyak penghuni rumah yang berkumpul dalam satu ruangan, kemungkinan risiko untuk terjadinya penularan suatu penyakit akan lebih mudah, khususnya bagi balita yang relatif rentan terhadap penularan penyakit. ${ }^{(10)}$

Setiap rumah sudah diberi ventilasi, tetapi belum berfungsi maksimal karena selalu tertutup dan bahkan tidak bisa dibuka karena ditutupi bilahan bambu, hal ini menyebabkan sirkulasi udara di dalam ruangan kurang baik, dan sinar matahari kurang masuk. Ventilasi mempunyai fungsi sebagai sarana sirkulasi 
udara segar masuk ke dalam rumah dan udara kotor ke luar rumah. Rumah yang tidak dilengkapi sarana ventilasi akan menyebabkan suplai udara segar ke dalam rumah menjadi sangat minimal. Kecukupan udara segar dalam rumah menjadi sangat dibutuhkan untuk kehidupan bagi penghuninya, karena ketidakcukupan suplai udara akan berpengaruh pada fungsi fisiologis alat pernafasan bagi penghuninya, terutama bayi dan balita. ${ }^{(10)}$

Disamping itu kebiasaan masyarakat Maumere, Flores yang menggunakan kompor minyak dan bahan bakar kayu menambah polusi di dalam rumah, ditambah lagi angka perokok di dalam rumah yang tinggi menambah besar polusi di dalam rumah. Asap dari bahan bakar kayu merupakan faktor risiko terhadap kejadian pneumonia pada balita. Penelitian Yuwono ${ }^{(11)}$ menunjukkan anak balita yang tinggal di rumah dengan jenis bahan bakar yang digunakan adalah kayu memiliki risiko terkena pneumonia sebesar 2,8 kali lebih besar dibandingkan anak balita yang tinggal di rumah dengan jenis bahan bakar minyak/gas. Polusi udara di dalam rumah juga dapat disebabkan oleh asap rokok, alat pemanas ruangan, dan juga akibat pembakaran yang tidak sempurna dari kendaraan bermotor. Hal ini juga didukung oleh penelitian Ezzati dan Kammen $^{(12)}$ yang menyatakan bahwa pajanan terhadap partikel debu dari pembakaran biomassa berhubungan dengan terjadinya infeksi saluran pernafasan akut.

\section{KESIMPULAN}

Hampir semua faktor risiko yang mendukung terjadinya pneumonia pada balita, yaitu umur, jenis kelamin, status gizi, dan karakteristik lingkungan, terdapat di Maumere. Flores NTT. Hal ini diperparah dengan masih banyaknya balita gizi kurang dan buruk; kurangnya kesadaran masyarakat untuk segera memeriksakan ke petugas kesehatan apabila anaknya mengalami keluhan batuk pilek; serta sarana dan prasarana yang belum memadai dalam proses rujukan.

\section{KEPUSTAKAAN}

1. Kemenkes RI. Modul dan Tatalaksana Standar Pneumonia. Direktorat Jenderal Pengendalian Penyakit dan Penyakit Lingkungan. Jakarta: Kemenkes RI; 2012.

2. WHO, UNICEF. Pneumonia: The Forgotten Killer of Children. Geneva: WHO Press; 2012.

3. Said M. Pneumonia. In: Rahajoe NN, Supriyatno B, Setyanto DB, editors. Buku Ajar Respirologi Anak. Edisi I. Jakarta: Penerbit IDAI; 2008.

4. Kemenkes RI. Riset Kesehatan Dasar. Jakarta: Kemenkes RI. 2013. 
5. Kemenkes RI. Riset Kesehatan Dasar Provinsi Nusa Tenggara Timur. Jakarta: Kemenkes RI, 2008.

6. Rencana Pengelolaan Jangka Panjang Taman Wisata Laut Gugus Pulau Teluk Maumere [Internet]. Kementerian Kehutanan Direktorat Jenderal Perlindungan Hutan Dan Konservasi Alam Balai Besar Konservasi Sumber Daya Alam Nusa Tenggara Timur. 2011. [cited 9 September 2015]. Available from: <http://bbksdantt.dephut.go.id/PDF/TWL_M aumere/REVIEW_RP_MAUMERE.pdf.>

7. Athena A, Dharmayanti I. Pneumonia pada Anak Balita di Indonesia. Jurnal Kesehatan Masyarakat Nasional 2014;8(8):359-65.

8. Gould D, Brooker C. Mikrobiologi Terapan Untuk Perawat. Jakarta: EGC; 2003.

9. Nurjazuli, Widyaningtyas R. Faktor Risiko Dominan Kejadian Pnumonia Pada Balita. Jurnal Respirologi Indonesia. 2009.

10. Kasjono HS, Fauziah S. Hubungan Faktor Lingkungan Fisik Rumah dengan Kejadian Pneumonia Pada Anak Balita di Wilayah Kerja Puskesmas Banguntapan II Berita Kedokteran Masyarakat. 2005.

11. Yuwono TA. Faktor-faktor Lingkungan Fisik Rumah yang Berhubungan dengan Kejadian Pneumonia pada Anak Balita di Wilayah Kerja Puskesmas Kawunganten Kabupaten Cilacap. Semarang: Universitas Diponegoro; 2008.
12. Ezzati M, Kammen DM. Quantifying the effects of exposure to indoor air pollution from biomass combustion on acute respiratory infections in developing countries. Journal of Environmental Health Perspectives. 2001.;109(5):481-8. 